\title{
Cell-mediated cytotoxic islet cell surface antibodies to human pancreatic beta cells
}

\author{
T. Maruyama ${ }^{1}$, I.Takei ${ }^{1}$, I. Matsuba ${ }^{2}$, A. Tsuruoka ${ }^{2}$, M.Taniyama $^{1}$, Y.Ikeda ${ }^{2}$, K. Kataoka ${ }^{1}$, M. Abe ${ }^{2}$ and S. Matsuki ${ }^{1}$ \\ ${ }^{1}$ Department of Internal Medicine, School of Medicine, Keio University, and \\ ${ }^{2}$ Third Department of Internal Medicine, Jikei University School of Medicine, Tokyo, Japan
}

Summary. Sera containing islet cell surface antibodies show a complement-dependent cytotoxic reaction against islet cells, but it has not yet been clarified whether islet cell surface antibodies exhibit cell-mediated cytotoxicity to these cells. By ${ }^{51} \mathrm{Cr}$ release assay we investigated whether islet cell surface antibodies showed a cytotoxic reaction to human pancreatic B cells (JHPI-1 clone) in the presence of normal human lymphocytes. The sera from 14 islet cell surface antibody-positive, 16 islet cell surface antibody-negative Type 1 (insulin-dependent) diabetic patients and 18 islet cell surface antibody-negative healthy subjects were studied. Four sera con- taining islet cell surface antibodies showed specific cytotoxicity above the mean $+3 S D$ value of healthy subjects, and the mean specific cytotoxicity of islet cell surface antibody-positive sera differed significantly from that of both islet cell surface antibody-negative groups. These results suggest that this cell-mediated cytotoxic mechanism may play an important role in the pathogenesis of Type 1 diabetes.

Key words: Type 1 diabetes, islet cell surface antibodies, cytotoxic antibodies, antibody-dependent cell-mediated cytotoxicity, human pancreatic B cells, islet cells.
It has been suggested that viral infections and the autoimmune process might play a pathogenic role in Type 1 (insulin-dependent) diabetes mellitus because of the presence of lymphocytic infiltration of the islets of Langerhans (insulitis) [1]. Especially in recent years, the autoimmune process has been considered an important factor in the development of Type 1 diabetes, as many patients with this disease possess humoral autoantibodies against islet cell cytoplasm and/or antibodies against the surface of islet $B$ cells $[2,3]$. Also, at the time of diagnosis, reduced suppressor cell activity [4] and an increase in the number of $\mathrm{K}$ cells [5] have been observed. In particular, islet cell surface antibodies (ICSA) are an important pathogenic factor in Type 1 diabetes, since they show cytotoxicity to rat pancreatic islet cells in the presence of complement $[6,7]$. It is generally accepted that antibody-dependent cell-mediated cytotoxicity may play an important role in the pathogenesis of organ-specific autoimmune disease [8], but it has not yet been reported whether ICSA exhibit cell-mediated cytotoxicity to pancreatic B cells. Therefore, using a ${ }^{51} \mathrm{Cr}$ release assay, we studied the cytotoxicity of ICSA to human pancreatic B cells (JHPI-1 clone) [9] in the presence of normal human lymphocytes.

\section{Materials and methods}

\section{Serum samples}

Fourteen ICSA-positive diabetic sera were obtained from 10 patients with Type 1 diabetes (five males, five females, mean age 23 years, range 3-61 years, mean duration of diabetes 3 years, range $0.2-10$ years) and four patients with Type 2 (non-insulin-dependent) diabetes (three males, one female, mean age 45 years, range $34-55$ years, mean duration of diabetes 13 years, range 1-34 years). Sixteen ICSA-negative sera obtained from patients with Type 1 diabetes (seven males, nine females, mean age 21 years, range 3-65 years, mean duration of diabetes 3 years, range $0.1-10$ years) and 18 ICSA-negative sera obtained from healthy subjects (ten males, eight females, mean age 32 years, range $24-52$ years) were also studied. Clinical details of the 14 patients with ICSA-positive sera are shown in Table 1. Islet cell surface antibodies were detected by the indirect immunofluorescence method using suspensions of viable BALB/c mouse islet cells $[3,10]$. Briefly, the isolated islets were separated from the collagenase-digest by Percoll-gradient centrifugation and then individually chosen with the aid of a stereomicroscope. The islets were suspended in $1 \mathrm{ml}$ RPMI-1640 medium supplemented with 1\% BSA and 2 mmol EGTA, and were dissociated into a single cell suspension by aspiration of the islet mixture five to ten times through a Pasteur pipette with a constricted tip. Suspensions of $5 \times 10^{4}$ cells were incubated in heat-inactivated serum $\left(1: 2\right.$ dilution) for $60 \mathrm{~min}$ at $4^{\circ} \mathrm{C}$, then washed three times with RPMI-1640 medium supplemented with $4 \%$ BSA. The cells were resuspended in $100 \mu \mathrm{l}$ fluorescein isothiocyanate (FITC) labelled anti- 
Table 1. Clinical details of patients with sera containing islet cell surface antibodies

\begin{tabular}{llcc}
\hline $\begin{array}{l}\text { Diabetic } \\
\text { patients }\end{array}$ & Sex & $\begin{array}{l}\text { Age } \\
\text { (years) }\end{array}$ & $\begin{array}{l}\text { Duration of } \\
\text { diabetes (years) }\end{array}$ \\
\hline Type 1 & & & \\
1 & F & 21 & 0.2 \\
2 & M & 54 & 4 \\
3 & F & 8 & 2 \\
4 & F & 28 & 10 \\
5 & F & 61 & 0.5 \\
6 & M & 21 & 0.4 \\
7 & M & 13 & 0.3 \\
8 & M & 3 & 0.4 \\
9 & M & 11 & 8 \\
10 & F & 9 & 4 \\
Type 2 & & & \\
11 & F & 34 & 4 \\
12 & M & 35 & 16 \\
13 & M & 54 & 34 \\
14 & M & 55 & 1 \\
\hline
\end{tabular}

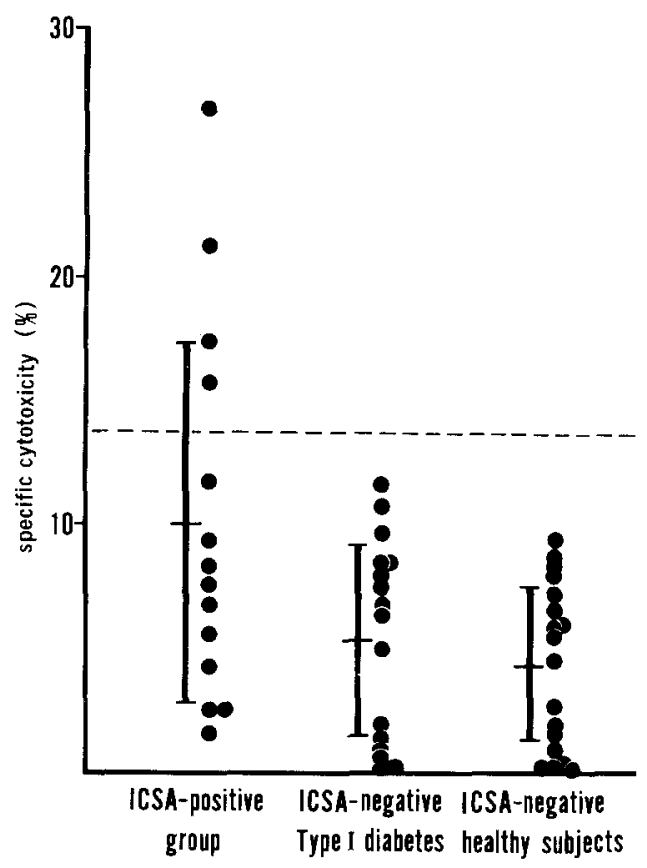

Fig. 1. ${ }^{51} \mathrm{Cr}$ release from human pancreatic B cells (percentage specific cytotoxicity) in the presence of healthy human lymphocytes and heat inactivated serum. Specific cytotoxicity was calculated from ${ }^{51} \mathrm{Cr}$ release as described in Methods. Mean cytotoxicity was significantly greater in the ICSA-positive group $(10.1 \pm 7.3 \%)$ compared with the ICSA-negative Type 1 diabetes group $(5.38 \pm 3.9 \%, p<0.05)$ and healthy controls $(4.29 \pm 3.25, p<0.01)$. The dotted line indicates 3SD above the normal mean value

human IgG (Behring Institute, Marburg, FRG, diluted 1:15 times in RPMI-1640 medium supplemented with 4\% BSA) and incubated for $60 \mathrm{~min}$ at $4^{\circ} \mathrm{C}$. The cells were then washed as above, and evaluated by fluorescence microscopy. All sera samples were stored at $-20^{\circ} \mathrm{C}$ and heat-inactivated $\left(56^{\circ} \mathrm{C}\right.$ for $\left.30 \mathrm{~min}\right)$ before use.

\section{Preparation of human pancreatic $B$ cells}

A human pancreatic B cell JHPI-1 clone was established from a human fetal pancreas at the 22-week gestational stage by the single cell plating feeder layer method using a modified Rose's chamber [9]. The JHPI-1 cells are an established cell line which secrete insulin [9]. Previous studies using an ${ }^{125} \mathrm{I}$-Protein A radioligand assay and an immunofluorescence method have demonstrated a good correlationship between the results obtained using two different antigens, i.e. JHPI-1 cells and BALB/c mouse islet cells [11]. The JHPI- 1 cells and pancreatic islet cells of the BALB/c mouse are thought to have common antigens on the cell membrane [11]. In the present study, 14 sera were examined by the indirect immunofluorescence method using both JHPI-1 cells and BALB/c mouse islet cells, and the two different cell antigens yielded identical results for each of the 14 sera tested.

\section{Cytotoxic assay}

Suspensions of human pancreatic B cells (JHPI-1 clone) were incubated at $37^{\circ} \mathrm{C}$ for $60 \mathrm{~min}$ in $1 \mathrm{ml}$ RPMI-1640 medium supplemented with $10 \%$ heat-inactivated $\left(56^{\circ} \mathrm{C}\right.$ for $\left.30 \mathrm{~min}\right)$ fetal calf serum and $0.05 \mathrm{mCi} \mathrm{Na}_{2}{ }^{51} \mathrm{CrO}_{4}$ (Daiichi Radioisotope Laboratories, Tokyo, Japan). After incubation, the cells were washed three times by centrifugation ( $450 \mathrm{rev} / \mathrm{min}$ for $20 \mathrm{~min}$ ) in RPMI- 1640 medium supplemented with heat-inactivated fetal calf serum, and used as target cells. Human lymphocytes were obtained from healthy donors (males aged 25-31 years, who had neither diabetic parents nor siblings), and the cells were isolated by centrifugation on a sodium Metrizoate-Ficoll gradient (Lymphoprep, Nyegaard, Oslo, Norway). The lymphocytes were washed three times by centrifugation $(100 \mathrm{rev} / \mathrm{min}$ for $5 \mathrm{~min})$ in Hanks balanced salt solution and after washing they were suspended in RPMI-1640 medium supplemented with 10\% heat-inactivated fetal calf serum. After pre-incubation at $37^{\circ} \mathrm{C}$ in $5 \% \mathrm{CO}_{2}$ for $30-60 \mathrm{~min}$, these lymphocytes were used as effector cells. Suspensions of $1 \times 10^{4}$ target cells were incubated at $37^{\circ} \mathrm{C}$ in $5 \% \mathrm{CO}_{2}$ for $5 \mathrm{~h}$ with effector cells $\left(1 \times 10^{6}\right)$ and $200 \mu \mathrm{l}$ of test serum diluted $1: 4$ in RPMI-1640 medium containing $10 \%$ heat-inactivated fetal calf serum. After incubation, released ${ }^{51} \mathrm{Cr}$ was counted in a gamma counter (Aloka, Tokyo, Japan). The release of ${ }^{51} \mathrm{Cr}$ was calculated as follows:

${ }^{51} \mathrm{Cr}$ release $=\frac{\mathrm{cpm} \text { released into medium }}{\text { total cpm (cells }+ \text { medium })} \times 100(\%)$

and the specific cytotoxicity was calculated by subtracting the percentage of ${ }^{51} \mathrm{Cr}$ released into the medium in the presence of test serum and effector cells from that released in the medium alone. Specificity was examined using Chang-liver cells as target cells. The results were calculated by Student's t-test.

\section{Results}

Four ICSA-positive sera showed specific cytotoxicity to human pancreatic B cells well above the mean +3SD value of healthy subjects in the presence of healthy human lymphocytes (Fig.1). None of the ICSA-negative Type 1 diabetes sera or healthy control sera showed specific cytotoxicity above this value. The mean specific cytotoxicity of ICSA-positive sera $(10.1 \pm 7.3 \%$ : mean $\pm S D$ ) differed significantly from that of the ICSA-negative Type 1 diabetes group $(5.38 \pm 3.9 \%, p<$ $0.05)$ and that of the ICSA-negative healthy subjects $(4.29 \pm 3.25 \%, p<0.01)$ in the presence of healthy human lymphocytes. In contrast, there was no significant difference between the mean specific cytotoxicity of the ICSA-negative Type 1 diabetic sera and that of healthy subjects. Definite cytotoxicity was demonstratable only when both antibodies and human lymphocytes were 


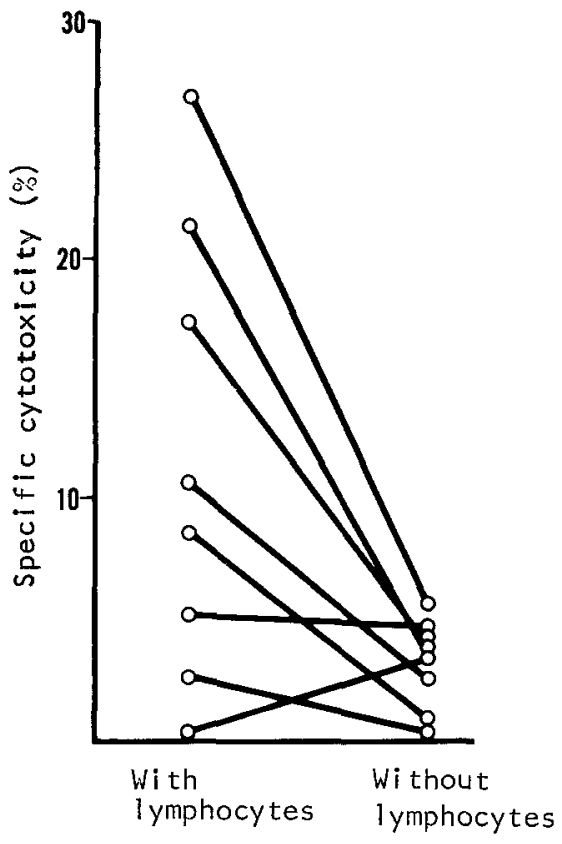

Fig. 2. Specific cytotoxicity of ICSA-positive sera in the presence or absence of healthy human lymphocytes

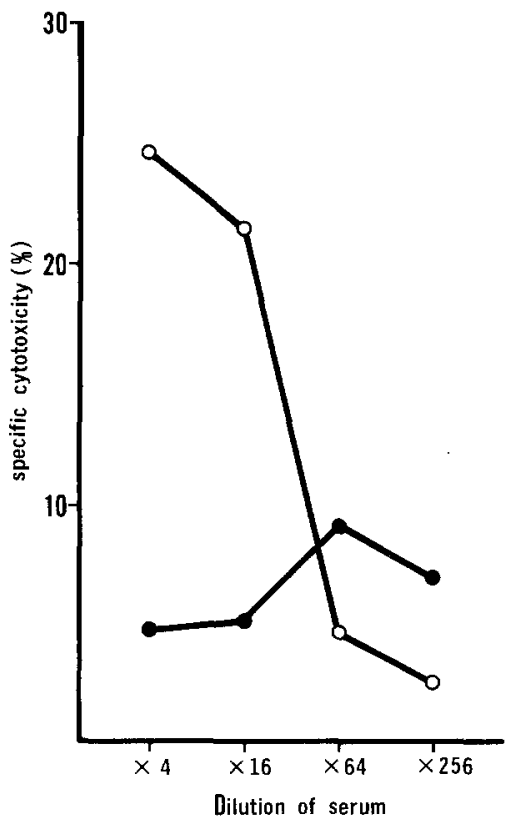

Fig.3. Correlation between the specific cytotoxicity to human pancreatic $\mathrm{B}$ cells and serum dilution. $\mathrm{O}-\mathrm{O}$ : cytotoxic serum. normal serum

present in the incubation mixture. In the absence of lymphocytes, there was essentially no cytotoxicity (Fig. 2). The strongest cytotoxic serum was studied in dilution from $1: 4$ to $1: 256$. At $1: 16$ dilution the serum was cytotoxic, but at 1:64 dilution the serum showed no cytotoxicity to the cells (Fig.3). One serum which showed strong cytotoxicity above the mean +3 SD value of normal subjects was obtained from a patient with
Type 2 diabetes. None of the four sera that showed a high level of cytotoxicity to human pancreatic B cells was positively cytotoxic to Chang-liver cells in the presence of healthy human lymphocytes.

\section{Discussion}

Our results demonstrate that some ICSA-positive sera are cytotoxic to human pancreatic B cells (JHPI-1 clone) in the presence of healthy human lymphocytes. This cytotoxicity does not occur without lymphocytes, and ICSA-negative Type 1 diabetic sera do not show such cytotoxicity. The cytotoxicity is due to the antibody-dependent cell-mediated cytotoxicity mechanism, i.e. cell-mediated ICSA and non-specific lymphocytes [12], and differs from complement-dependent cytotoxicity $[6,7]$. It is suggested that the cell-mediated cytotoxicity is specific to pancreatic B cells, as no positive cytotoxicity was found with Chang-liver cells.

Although the mean specific cytotoxicity of ICSApositive sera differed from that of ICSA-negative groups, all ICSA-positive sera did not show strong cytotoxicity above the mean $+3 S D$ value of the healthy subjects. Since the cytotoxicity disappears upon dilution of the serum, a fixed amount of antibody is considered to be necessary for cytotoxic activity. It remains to be proven whether this difference originates from the concentration ratio of antibody to antigen or the possible heterogeneity of ICSA.

One of the four sera that showed strong cytotoxicity was obtained from a patient with Type 2 diabetes treated with diet therapy. As complement-dependent cytotoxicity is observed in ICSA-positive sera of patients without diabetes [6] so also was antibody-dependent cell-mediated cytotoxicity found in one ICSA-positive sera from a patient without Type 1 diabetes. On the other hand, it has been reported that islet cell antibody (ICA) is present in the sera of some patients before the development of Type 1 diabetes [13] and that patients with ICA-positive Type 2 diabetes frequently become insulin dependent [14]. By analogy, if the cytotoxicity exists in vivo, our Type 2 diabetic patient with strong cell-mediated cytotoxic ICSA may possibly become insulin-dependent in the future.

In the presence of specific antibody, non-specific lymphocytes show cytotoxicity, as is seen in organspecific autoimmune diseases, such as Hashimoto's thyroiditis [15], and this is considered an important pathogenesis of these diseases. Type 1 diabetes is frequently associated with Hashimoto's thyroiditis, Addison's disease and other organ-specific autoimmune diseases $[16,17]$. Thus, in addition to the presence of ICA and ICSA, an increase in the number of K cells [5], increased antibody-dependent cell-mediated cytotoxicity activity of lymphocytes from Type 1 diabetes [18], and a decrease in suppressor $T$ cells [4] and other immunoabnormalities [19-21] are all observed. Furthermore, 
it has been reported that lymphocytes from patients with Type 1 diabetes destroy insulinoma cells [22]. Therefore it is suggested that cytotoxic reaction to pancreatic $B$ cells by non-specific lymphocytes and cell-mediated cytotoxic ICSA may play an important role in the pathogenesis of Type 1 diabetes together with the above-described humoral and cellular immunological abnormalities.

Acknowledgement. We are grateful to Dr. A.. Lernmark for his technical advice and continuous encouragement of this study.

\section{Reference}

1. Gepts W (1965) Pathologic anatomy of the pancreas in juvenile diabetes. Diabetes 14: 619-633

2. Bottazzo GF, Florin-Christensen AN, Doniach D (1974) Islet cell antibodies in diabetes mellitus with autoimmune polyendocrine deficiencies. Lancet 2: 1279-1283

3. Lernmark Ä, Freedman ZR, Hoffmann C, Rubenstein AH, Steiner DF, Jackson RL, Winter RJ, Traisman HS (1978) Islet cell surface antibodies in juvenile diabetes mellitus. N Engl $\boldsymbol{J}$ Med 229: $375-380$

4. Fairchild RS, Kyner JL, Abdou NI (1982) Specific immunoregulation abnormality in insulin-dependent diabetes mellitus. J Lab Clin Med 99: 175-186

5. Pozzilli P, Sensi M, Gorsuch A, Bottazzo GF, Cudworth AG (1979) Evidence for raised K cell levels in Type 1 diabetes. Lancet 2: $173-175$

6. Dobersen MN, Scharff JE, Ginsberg-Fellner F, Notkins AL (1980) Cytotoxic autoantibodies to beta cells in the serum of patients with insulin-dependent diabetes mellitus. $N$ Engl J Med 303: 1493-1498

7. Kanatsuna T, Lernmark $\AA$, Rubenstein AH, Steiner DF (1981) Block in insulin release from column-perifused pancreatic $\beta$-cells induced by cell surface antibodies and complement. Diabetes. 30 : 231-234

8. LiShem P, Lydyard P, Penforld P, Roitt IM (1979) Evidence for antibody-dependent cell-mediated cytotoxicity by T-cells bearing receptors for Ig-G. Clin Exp Immunol 35: 276-285

9. Matsuba I, Tanese T, Abe M (1982) Human pancreatic islet cell clones secreting insulin, glucagon and somatostatin: immunocytochemical and functional studies. Arch Histol Jap 45: 111-119

10. Lernmark $\AA$, Kanatsuna T, Patzelt C, Diakoumis K, Carroll R, Rubenstein AH, Steiner DF (1980) Antibodies directed against the pancreatic islet cell plasma membrane. Diabetologia 19: 445-451
11. Maruyama T, Takei I, Matsuba I, Tsuruoka A, Ikeda Y, Kataoka K, Abe M, Matsuki S (1983) Detection of islet cell surface antibodies using cultured human pancreatic beta cells (JHPI-1 clone). Folia Endcrinol Jap 59: 470 (Abstract)

12. MacLennan ICM, Lawewi G (1968) Effect of specific antibody to target cells on their specific and nonspecific interaction with lymphocytes. Nature 219: 1069-1071

13. Spikanta S, Ganda OP, Eisenbarth GS, Soeldner JS (1983) Isletcell antibodies and beta-cell function in monozygotic triplets and twins initially discordant for Type 1 diabetes mellitus. N Engl J Med 308: 322-325

14. Irvine WJ, Gray RS, Steel JM (1980) Islet cell antibody as a marker for early stage Type 1 diabetes mellitus. In: Irvine WJ (ed) Immunology of diabetes. Teviot, Edinburgh, pp 117-154

15. Calder EA, Penhale WJ, Mcleman D, Barnes EW, Irvine WJ (1973) Lymphocyte-dependent antibody-mediated cytotoxicity in Hashimoto's thyroiditis. Clin Exp Immunol 14: 153-158

16. Irvine WJ (1980) Immunological aspect of diabetes mellitus: a review (including the salient points of the NDDG report on the classification of diabetes). In: Irvine WJ (ed) Immunology of diabetes. Teviot, Edinburgh, pp 1-53

17. Gray RS, Irvine WJ, Toft AD, Seth J, Cameron EHD, Clarke BF (1979) Unrecognized thyroid failure in diabetes mellitus. J Clin Lab Immunol 2: 221-224

18. Sensi M, Pozzilli P, Gorsuch AN, Bottazzo GF, Cudworth AG (1981) Increased killer cell activity in Type 1 (insulin-dependent) diabetes mellitus. Diabetologia 20: 106-109

19. Irvine WJ, DiMario U, Guy K, Gray RS, Duncan LJP (1980) Immune complex in newly diagnosed insulin-dependent (Type 1) diabetes. In: Irvine WJ (ed) Immunology of diabetes. Teviot, Edinburgh, pp 219-227

20. Cudworth AG, Bottazzo GF, Doniach D (1980) Genetic and immunological factors in Type 1 diabetes. In: Irvine WJ (ed) Immunology of diabetes. Teviot, Edinburgh, pp 67-107

21. Boitard C, Debray-Sachs M, Pouplard A, Assan R, Hamburger J (1981) Lymphocytes from diabetics suppress insulin release in vitro. Diabetologia 21: 41-46

22. Huang S-W, MacLaren NK (1976) Insulin-dependent diabetes: A disease of autoaggression. Science 192: 64-66

Dr. Taro Maruyama

Department of Internal Medicine, School of Medicine

Keio University

35 Shinanomachi, Shinjuku-ku, Tokyo 160

Japan 